\title{
Effect of probiotic supplements on productivity and meat quality of broilers
}

\author{
F.N. Tsogoeva ${ }^{1}$, I.I. Ktsoeva ${ }^{1}$, L.A. Vityuk ${ }^{2}$, R.B. Temiraev ${ }^{1,2}$, M.T. \\ Shaov $^{3}$, V.S. Gappoeva ${ }^{4}$, I.V. Kochieva ${ }^{2}$
}

${ }^{1}$ Gorsky State Agrarian University, 362040, Vladikavkaz, 37 Kirov Street; ${ }^{2}$ North-Caucasian Mining and
Metallurgical Institute (State Technological University), Vladikavkaz 362021; ${ }^{3}$ Kabardino-Balkarian State
University named after H.M. Berbekov, 360004,Kabardino-Balkarian Republic, Nalchik, Chernyshevsky St., 173.
${ }^{4}$ North-Ossetian State University named after K.L. Khetagurov, Vladikavkaz, 362025, Russian Federation.
${ }^{*}$ Corresponding author e-mail: temiraev@ mail.ru

Journal of Livestock Science (ISSN online 2277-6214) 12: 346-350

Received on 3/10/21; Accepted on20/11/21; Published on 10/12/21

doi. 10.33259/JLivestSci.2021.346-350

\begin{abstract}
The purpose of the research was to study the effectiveness of using the probiotic BifidumSChZh, vitamin E and sodium selenite in diets with an excessive content of Heavy Metals (HM in future) salts to increase meat productivity and consumer qualities of broiler meat. From chickens at one day of age, according to the principle of analog groups, we formed 4 groups of 200 heads each. It was found that broiler chickens 3 experienced were distinguished by the best slaughter characteristics due to the high detoxification effect with joint additions to the composition of diets with an excess content of HM salts of probiotic, vitamin E and sodium selenite. Moreover, in the meat poultry of this group during the present experiment, compared with the analogs of the control group, higher indicators of the mass of a half-gutted carcass were observed by $11.93 \%$, gutted - by $12.23 \%$, slaughter yield - by $1.11 \%$. With the combined use of a probiotic and two antioxidants in the compound feed formulation, samples of white meat from broilers of the 3rd experimental group were distinguished by the best nutritional properties, in which, relative to analogs from the control group, in the samples of pectoral muscles, the dry matter concentration increased by $1.12 \%$, protein - by $1.14 \%$ while reducing the level of fat - by $0.40 \%$. It was found that due to the efficiency of detoxification of toxicants during joint feeding of tested drugs against poultry of the control group in broilers of the 3rd experimental group in samples of pectoral muscle (white meat) there was an increase in the concentration of the amino acid tryptophan by $0.11 \%$, which provided significant increase in the value of meat PQI - by $15.96 \%$. Due to this, the poultry of this group in the pectoral muscle samples contained less zinc -2.71 times, cadmium -2.57 and lead -2.65 times.
\end{abstract}

Key words: meat chickens, probiotic; antioxidants; meat productivity; nutritional properties of meat;environmental safety. 


\section{Introduction}

In recent years, among all types of meat in our country, the highest growth rates have been demonstrated by the production of poultry meat. New fast-growing crosses of meat poultry have appeared which in a short time frame make it possible to obtain a large volume of dietary meat, which is distinguished by high nutritional properties and biological value of protein, the presence of unsaturated fatty acids. However, young meat poultry, due to the immaturity of the digestive system in the first weeks of life, is extremely sensitive to environmental factors, including feeding conditions and the ecological safety of feed ingredients (Kononenko et al., 2012;Sukhanova et al., 2018; Tsogoev et al., 2002).

For the successful realization of the genetically determined productive potential of meat poultry, it is necessary to ensure not only the organization of feeding with complete balanced types of compound feed, but also strictly monitor the environmental characteristics of each individual component of these compound feed. If you do not comply with this requirement, then with a good diet due to the presence of any type of toxins, there may be a decrease in growth rates, deterioration of food and sanitary and hygienic characteristics of broiler chicken meat (Kizinov et al., 2004; Temiraev et al., 2020;Tletseruk et al., 2013;Temiraev et al., 2008).

In the conditions of the industrial zone of the Republic of North Ossetia - Alania, due to the presence of heavy metal salts in excess concentrations due to the presence of large non-ferrous metallurgy plants in the city of Vladikavkaz, which for many decades served as sources of emissions in large quantities of these toxic compounds. HM salts, possessing the property of gradual accumulation in organs and tissues, poison the body of broilers, worsening the ecological safety of their meat (Kokaeva et al., 2020). Along with this, due to the high air humidity, forage crops, especially cereals, are often doomed to oxidize crude fat with the formation of peroxides in them. The latter becomes a source of free radicals formation in the body of poultry, which destroy cell membranes and contribute to the acceleration of aging of the body, inhibition of metabolism, growth and development (Temiraev et al., 2012).

To eliminate the indicated negative consequences with the indicated disadvantages of feeding conditions when feeding antioxidant preparations, a number of researchers have established a positive effect on the metabolism, growth energy and consumer properties of the produced poultry meat. A particularly high effect is observed with the combined feeding of natural antioxidants vitamin E (tocopherol) and selenium, which show a complementary effect on the poultry organism (Gadzaonov et al., 2009; Vityuk et al., 2017; Kokaeva et al., 2017).

It is also known that with an excessive intake of peroxides and HM salts in the gastrointestinal tract (GIT) of broilers, suppression of beneficial microflora is observed, which causes disturbances in digestion. To remedy this situation, probiotic preparations are widely used in the diet of poultry, which contain live microorganisms of useful microflora, including bifidobacteria. At the same time, probiotics often demonstrate synergistic action with antioxidants (Stolbovskaya et al., 2013;Temiraev et al., 2009).

In this regard, the purpose of the research was to study the effectiveness of using the probiotic BifidumSChZh (manufactured by "Partner", Moscow), vitamin E and sodium selenite in diets with an excessive content of HM salts to increase meat productivity and consumer qualities of broiler meat.

\section{Material and methods}

While realizing this goal on broilers of the cross "ROSS-308" in the conditions of LLC "Iraf-Agro" (Irafsky district of North Ossetia - Alania), a scientific and production experiment was carried out. From chickens at one day of age, according to the principle of analog groups, we formed 4 groups of 200 heads each. The bird was fattened for 42 days when the experimental bird was kept in KBN-3 cage batteries.All analysis took place at Gorsky State Agrarian University (Vladikavkaz, North Ossetia-Alania, Russia).

Feeding broiler chickens of the compared groups was carried out in accordance with the experimental scheme (Table 1) with complete feed (CF), in which the tested preparations were introduced in a multistage method using standard dispensers. Table 2 shows the compound feed formulation for the experimental poultry.

On an atomic adsorption spectrophotometer AAZ-115-M1, the presence of HM salts in the taken average samples of complete feed was regularly determined. At the same time, it was found that in the course of the scientific and economic experience in the experimental poultry in the compound feeds CF-5 and CF-6, there was an excess of the maximum permissible concentrations (MPC) for the presence of cadmium by 25.3 and $20.7 \%$, zinc by 30,8 and $29.7 \%$ and lead - by 27.6 and $28.8 \%$, respectively.

Upon reaching the age of 42 days, 5 meat chickens, typical in terms of live weight and condition, were selected from each group, which were subjected to control slaughter according to the traditional method. The slaughter and meat qualities of the experimental poultry were studied according to generally accepted methods.

Next, we processed all the experimental material statistically with the derivation of the Student's test on a PC using software. 
Table 1. Scheme of scientific and economic experience on broilers $(n=200)$

\begin{tabular}{|l|l|}
\hline Group & \multicolumn{1}{|c|}{ Feeding features } \\
\hline Control & Complete feed $(\mathrm{CF})$ \\
\hline I & CF + BifidumSKhZh at the rate of 5 doses per 200 head \\
\hline II & $\begin{array}{l}\text { CF }+ \text { sodium selenite at a dose of } 0.2 \mathrm{mg} / \mathrm{kg} \text { feed }+ \text { tocopherol at a dose of } 25 \\
\text { thousand IU } / \mathrm{t} \text { feed }\end{array}$ \\
\hline III & $\begin{array}{l}\text { CF }+ \text { Bifidum SHG at the rate of } 5 \text { doses per } 200 \text { animals }+ \text { sodium selenite at a } \\
\text { dose of } 0.2 \mathrm{mg} / \mathrm{kg} \text { feed }+ \text { tocopherol at a dose of 25 thousand IU / t of feed }\end{array}$ \\
\hline
\end{tabular}

Table 2. Composition and nutritional value of broiler chicken feed

\begin{tabular}{|l|c|}
\hline \multicolumn{1}{|c|}{ Composition } & Contained \\
\hline Barley grain, $\%$ & 42.0 \\
\hline Corn grain, $\%$ & 17.5 \\
\hline Soybean grain, $\%$ & 17.0 \\
\hline Sunflower cake, $\%$ & 4.3 \\
\hline Wheat bran, $\%$ & 5.0 \\
\hline Fodder yeast, $\%$ & 6.5 \\
\hline Fish flour, $\%$ & 2.9 \\
\hline Table salt, $\%$ & 0.3 \\
\hline Dicalcium phosphate, $\%$ & 2.9 \\
\hline Premix P6-1-06, $\%$ & 1.0 \\
\hline 100 g of compound feed contains: & \\
\hline exchange energy, kJ & 1.340 \\
\hline crude protein, g & 21.11 \\
\hline crude fat, g & 4.11 \\
\hline crude fiber, g & 4.22 \\
\hline calcium, g & 1.27 \\
\hline phosphorus, g & 0.73 \\
\hline lysine, g & 1.44 \\
\hline cadmium, mg / kg & 0.48 \\
\hline zinc, mg / kg & 128.7 \\
\hline lead, mg / kg & 5.94 \\
\hline
\end{tabular}

\section{Results and discussion}

After the completion of the scientific and economic experiment, following the results of the control slaughter, the effect of the tested preparations on the slaughter performance of broilers from the compared groups was studied (Table 3).

It was found that broiler chickens 3 experienced were distinguished by the best slaughter characteristics due to the high detoxification effect with joint additions to the composition of diets with an excess content of HM salts of probiotic, vitamin $\mathrm{E}$ and sodium selenite.

Moreover, in the meat poultry of this group during the present experiment, compared with the analogs of the control group, higher indicators of the mass of a half-gutted carcass were observed by $11.93 \%(\mathrm{P}<0.05)$, gutted by $12.23 \%(\mathrm{P}<0.05)$, slaughter yield - by $1.11 \%(\mathrm{P}<0.05)$.

Along with this, against the poultry of the control group, when the probiotic and antioxidant preparations were fed together in broilers of the 3rd experimental group, an increase in the ratio of the mass of edibles to the mass of inedibles was noted - by $8.98 \%(\mathrm{P}<0.05)$ and the yield of carcasses of category $\mathrm{I}-$ by $11.35 \%(\mathrm{P}<0.05)$.

In carrying out the present, we paid special attention to the study of the influence of probiotic and antioxidant preparations on the chemical composition of the experimental poultry meat (Table 4).

With the combined use of a probiotic and two antioxidants (sodium selenite and tocopherol) in the compound feed formulation, samples of white meat from broilers of the 3rd experimental group were distinguished by the best nutritional properties, in which, relative to analogs from the control group, in the samples of pectoral muscles, the dry matter concentration increased by $1.12 \%(\mathrm{P}<0.05)$, protein - by $1.14 \%(\mathrm{P}<0.05)$ while reducing the level of fat - by $0.40 \%(\mathrm{P}<0.05)$.

Another important indicator characterizing the consumer properties of poultry meat is the biological value of chicken, assessed by the protein-quality indicator (PQI) of breast muscle samples (Table 5).

It was found that due to the efficiency of detoxification of toxicants during joint feeding of tested drugs against poultry of the control group in broilers of the 3rd experimental group in samples of pectoral muscle (white meat) there was an increase in the concentration of the amino acid tryptophan by $0.11 \%(\mathrm{P}<0.05)$, which provided significant $(\mathrm{P}<0.05)$ increase in the value of meat $\mathrm{PQI}-$ by $15.96 \%$. 
Along with this, the concentration of heavy metals: zinc lead and cadmium (Table 6) was studied in samples of the pectoral muscle of broilers from the compared groups.

It was found that in the course of the experiment, the process of elimination of HM salts, due to the synergistic action of the probiotic and antioxidant preparations, was more efficient in the body of poultry of the 3rd experimental group. Due to this, the poultry of this group in the pectoral muscle samples contained less zinc -2.71 times $(\mathrm{P}<0.05)$, cadmium - $2.57(\mathrm{P}<0.05)$ and lead -2.65 times $(\mathrm{P}<0.05)$. It should be noted that the level of zinc, cadmium and lead in the samples of white poultry meat of all experimental groups was lower than the MPC (Maximum Permissible Concentration) values.

Conclusion.Thus, in order to increase meat productivity, nutritional value and environmental safety of meat in the technogenic zone of the Republic of North Ossetia - Alania, it is advisable to jointly include the probiotic BifidumSKhZh in the diets of broilers with excessive levels of HM salts at the rate of 5 doses per 200 head, sodium selenite preparations in a dose $0.2 \mathrm{mg} / \mathrm{kg}$ feed and vitamin $\mathrm{E}$ at a dose of 25 thousand IU / $\mathrm{t}$ feed.

Table 3 - Slaughter indicators of the experimental bird $(n=5)$

\begin{tabular}{|l|l|l|l|l|}
\hline \multirow{2}{*}{\multicolumn{1}{|c|}{ Index }} & \multicolumn{3}{c|}{ Group } \\
\cline { 2 - 5 } & \multicolumn{1}{c|}{ control } & \multicolumn{1}{c|}{ I } & \multicolumn{1}{c|}{ II } \\
\hline Pre-slaughter weight of one head, g & $2350.10 \pm 5.2$ & $2502.32 \pm 5.1$ & $2508.38 \pm 5.3$ & $2594.33 \pm 5.0$ \\
\hline Half-gutted carcass weight, g & $1939.72 \pm 4.2$ & $2084.18 \pm 4.4$ & $2090.23 \pm 4.7$ & $2171.19 \pm 4.3$ \\
\hline In\% to live weight & 82.54 & 83.29 & 83.33 & 83.69 \\
\hline Gutted carcass weight, g & $1519.40 \pm 4.0$ & $1636.52 \pm 3.5$ & $1641.23 \pm 4.0$ & $1706.03 \pm 3.7$ \\
\hline Lethal output,\% & 64.65 & 65.40 & 65.43 & 65.76 \\
\hline
\end{tabular}

Table 4.Chemical composition of the pectoral muscle samples of the experimental bird during the experiment $(n=5)$

\begin{tabular}{|l|c|c|c|c|}
\hline \multirow{2}{*}{ Index } & \multicolumn{4}{|c|}{ Group } \\
\cline { 2 - 5 } & control & I & II & III \\
\hline Dry matter,\% & 24.45 & 25.12 & 25.16 & 25.60 \\
\hline Protein,\% & 20.70 & 21.67 & 21.70 & 22.01 \\
\hline Fat,\% $\%$ & 2.75 & 2.55 & 2.53 & 2.49 \\
\hline
\end{tabular}

Table 5 - Protein-quality indicator of poultry pectoral muscle samples $(n=5)$

\begin{tabular}{|l|l|l|l|l|}
\hline \multirow{2}{*}{ Index } & \multicolumn{4}{c|}{ Group } \\
\cline { 2 - 5 } & control & I & II & III \\
\hline Tryptophan, \% & $1.62 \pm 0.004$ & $1.69 \pm 0.006$ & $1.70 \pm 0.007$ & $1.73 \pm 0.005$ \\
\hline Oxyproline, \% & $0.38 \pm 0.003$ & $0.37 \pm 0.002$ & $0.37+0.004$ & $0.35 \pm 0.003$ \\
\hline Protein-quality index (PQI) & $4.26 \pm 0.09$ & $4.59 \pm 0.12$ & $4.60 \pm 0.14$ & $4.94 \pm 0.10$ \\
\hline
\end{tabular}

Table 6 - The content of heavy metals in the breast muscle of chickens $(n=5)$

\begin{tabular}{|l|l|l|l|l|}
\hline \multirow{2}{*}{ Index } & \multicolumn{4}{c|}{ Group } \\
\cline { 2 - 5 } & control & I & II & III \\
\hline Zinc $($ MPC $=70 \mathrm{mg} / \mathrm{kg})$ & $83.22 \pm 0.33$ & $62.48 \pm 0.30$ & $62.24 \pm 0.19$ & $30.65 \pm 0.28$ \\
\hline Cadmium $($ MPC $=0.05 \mathrm{mg} / \mathrm{kg})$ & $0.072 \pm 0.004$ & $0.043 \pm 0.002$ & $0.040 \pm 0.005$ & $0.028 \pm 0.002$ \\
\hline Lead $($ MPC $=0.5 \mathrm{mg} / \mathrm{kg}$ ) & $0.77 \pm 0.03$ & $0.46 \pm 0.05$ & $0.44 \pm 0.04$ & $0.29 \pm 0.03$ \\
\hline
\end{tabular}

\section{References}

1). GadzaonovR.Kh.,Stolbovskaya A.A., Baeva A.A., Kibizov G.K. 2009. Use of antioxidant and mold inhibitor in broilers feed. Poultry breeding.4:23-24.

2). Kizinov F.I., Temiraev R.B., Tsogoeva F.N., Gibizova I.T. 2004.Sodium selenite and vitamin E in feeding broiler chickens.News of the Mountain State Agrarian University, Vladikavkaz. 41:78-83.

3). Kokaeva, M.G., Temiraev, R.B., Beslaneev, E.V., Cherchesova S.K., Kubatieva (Gutieva), Z.A., Kozyrev, S.G. 2017. Influence of antioxidant and adsorbent on the process of digestive and intermediate metabolism in lacting cows during denitrification. Journal of Pharmaceutical Sciences and Research. 9 (12): 2401-2404.

4). KokaevaM.G., Temiraev R.B., Dzhaboeva A.S., Osikina R.V., Gazzaeva M.S., Shugusheva L.H., Sattsaeva I.K., Nerovnykh L.P., Arutyunova G.Y., Efendiev B.S. 2020. Method for increasing the ecological and food values of milk and dairy products. Journal of Livestock Science 11: 14-19.

5). Kononenko S.I., Tedtova V.V., Vityuk L.A., Salbieva F.T. 2012. Physiological and biochemical status of the organism of broiler chickens while improving the processing technology of fodder grain. Polythematic network electronic scientific journal of the Kuban State Agrarian University [Electronic resource]. Krasnodar: KubSAU, 10 (84). 
6). Stolbovskaya A.A., Temiraev R.B., Baeva A.A., Vityuk L.A. 2013. A method for increasing the productivity and consumer qualities of broiler meat while reducing the risk of aflatoxicosis. Vladikavkaz.Pp. 184.

7). Sukhanova S.F., Kononenko S.I., Temiraev R.B., Tarchokov T.T., Baeva Z.T., Bobyleva L.A., Shipshev B.M. 2018. Effect of antioxidants and probiotics on the indicators of natural resistance and peroxidation of lipids in poultry. Journal of Pharmaceutical Sciences and Research. 10(11):2969-2971.

8). Temiraev R.B., Baeva Z.T., Teziev U.I., Gazdarov A.A. 2009. How to protect dairy products from heavy metal contamination. Dairy Industry5:73-74.

9). Temiraev R.B., Kokaeva F.F., Tedtova V.V., Baeva A.A., Khadikova M.A., Abaev A.V. 2012. A method of increasing the dietary qualities of meat and improving metabolism in broiler chickens in the technogenic zone of the Republic of North Ossetia-Alania.News of the Mountain State Agrarian University.Vladikavkaz. 49(4):130-133.

10). Temiraev R.B., Kairov V.R., Khamitsaeva E.S., Tuaeva T.K. 2008. Heavy metal contamination: how to keep pork safe. Compound feed. 4:34-35.

11). Temiraev V.H., Baeva A.A., Vityuk L.A., Mamukaev M.N., Yurina N.A., Ktsoeva I.I., Bobyleva L.A., Zagaraeva E.F., Kokov T.N., Vologirova F.A. 2020. Effect of probiotics on digestive metabolism in growing and laying poultry birds. Journal of Livestock Science 11: 33-39.

12). Tletseruk I.R., Temiraev K.B., Tukkaev O.V., Abaev A.V. 2013. A way to improve the ecological and food qualities of poultry meat.New technologies. - Maykop. 3:128-134.

13). Tsogoev N.D., Temiraev R.B., Gagkoeva N.A., Gibizova I.T. 2002. The use of environmentally friendly biological products in the nutrition of broiler chickens.Bulletin of IASES. Vladikavkaz 9:125-127.

14). Vityuk L.A., Baeva A.A., Kochieva I.V., Stolbovskaya A.A., Kononenko S.I., Yarmoc A.V., Tletseruk I.R., Bobyleva L.A., Tsugkiev B.G., Sattsaeva I.K. 2017. Assessment of the productivity of broiler chicken sunder and the heavy metal detoxication in the context of industrial pollution. Pollution Research.36(4):748-754. 